\title{
SURGICAL MANAGEMENT IN GESTATIONAL TROPHOBLASTIC DISEASES
}

\author{
S. Sinan OZALP, Tufan OGE
}

Department of Gynecology and Obstetric, Faculty of Medicine, Osmangazi University, Eskişehir, Turkey

\section{SUMMARY}

Management of hydatidiform moles includes surgical evacuation and monitoring of human gonadotropin hormone. Hysterectomy may be an option particularly in patients who do not wish to preserve fertility. Although chemotherapy regimes are very effective for the treatment of malignant gestational trophoblastic neoplasia, hysterectomy and extirpation methods also play an important role especially in reducing the amount of chemotherapy and in cases exhibiting drug-insensitive diseases or hemorrhagic complications. This review discusses the indications and the role of surgical interventions during the medical management of women with hydatidiform moles and malignant gestational trophoblastic neoplasia.

Key words: gestational trophoblastic disease, hysterectomy, surgery

Journal of Turkish Society of Obstetrics and Gynecology, (J Turk Soc Obstet Gynecol), 2012; Vol: 9, Issue: 3, Pages: 133- 41

\section{GESTASYONEL TROFOBLASTIK HASTALIKLARDA CERRAHI YAKLAŞIMLAR}

\section{ÖZET}

Hidatiform mol hastalarına yaklaşım cerrahi olarak uterusun boşaltılması ve human koryonik gonadotropin (hCG) izlemi șeklindedir. Histerektomi özellikle fertilitesini korumayı arzulamayan hastalarda bir tedavi seçeneğidir. Malign gestasyonel trofoblastik neoplazilerde kemoterapinin etkinliğine rağmen özellikle total kemotarapi dozunun azaltılmasında, ilaca direnç gelișen ve kanama gelişen vakalarda histerektomi ile ekstirpasyon yöntemleri tedavide önemli rol oynarlar. Bu derlemede hidatiform mol ve malign gestasyonel trofoblastik neoplazilerde cerrahinin rolü ve endikasyonları tartıșılmıștır.

Anahtar kelimeler: cerrahi, gestasyonel trofoblastik hastalı, histerektomi

Türk Jinekoloji ve Obstetrik Derneği Dergisi, (J Turk Soc Obstet Gynecol), 2012; Cilt: 9, Sayl: 3, Sayfa: $133-41$

\section{INTRODUCTION}

Gestational trophoblastic diseases (GTDs) are histopathologically categorized in 4 main groups: hydatidiform mole (HM), invasive mole, choriocarcinoma, and trophoblastic tumors arising from placenta (placental site trophoblastic tumor). Currently, since the $\beta$ subunit of human chorionic gonadotropin (hCG) can be accurately measured and thus used as a tumor marker along with the efficacy of chemotherapy in this disease, even extensive forms of GTNs can be treated. Although GTN develops after HM, it may also ensue therapeutic or spontaneous abortion or term pregnancy(1-3).

Today, there is an ongoing discussion on whether histologic criteria could predict prognosis in trophoblastic diseases or not. According to the commonly recognized opinion, histologic criteria are regarded as inadequate for the prediction of prognosis. Furthermore, treatment can not be planned based on the histologic criteria because histologic diagnosis is

Address for Correspondence: Tufan Öge. Eskişehir Osmangazi Üniversitesi Kadın Hastalıkları ve Doğum Bölümü, 26480 Eskişehir Phone: +90 (506) 5015353

e-mail: tufanoge@yahoo.com

Received: 18 August 2011, revised: 29 September 2011, accepted: 11 October 2011, online publication: 
not present in all cases. Various staging and scoring systems have been proposed for the management of GTNs. Currently, the combined use of the staging system of Internation Federation of Gynecology and Obstetrics (FIGO) and the modified scoring system of the World Health Organization (WHO), are recommended $^{(4)}$. In this approach, it is aimed to reveal the efficacy of treatment by using a common system and comparing outcomes of different approaches. The recent FIGO staging system is shown in Table I and WHO scoring system is shown in Table II.

Table I: FIGO Staging System.

Stage I: GTN confined to the uterus
Stage II: GTN extends to the adnexa and vagina, but still
confined to the genital structures
Stage III: GTN extends to the lungs, with or without
involvement of genital system
Stage IV:

Table II: FIGO Risk Factor Scoring.

\begin{tabular}{|c|c|c|c|c|}
\hline Score System & $\mathbf{0}$ & 1 & 2 & 4 \\
\hline Age (years) & $<40$ & $\geq 40$ & - & - \\
\hline $\begin{array}{l}\text { Antecedent pregnancy } \\
\text { Interval from first }\end{array}$ & MH & Düşük & Term & - \\
\hline pregnancy (months) & $<4$ & $4-6$ & $7-12$ & $>12$ \\
\hline $\begin{array}{l}\text { Pretreatment serum } \\
\mathrm{hCG}(\mathrm{mIU} / \mathrm{ml})\end{array}$ & $<10^{3}$ & $10^{3}-10^{4}$ & $>10^{4}-10^{5}$ & $>10^{5}$ \\
\hline $\begin{array}{l}\text { Largest tumor size, } \\
\text { including uterus }(\mathrm{cm})\end{array}$ & & $3-4$ & $\geq 5$ & \\
\hline Metastase sites & Lung & $\begin{array}{l}\text { Spleen, } \\
\text { Kidney }\end{array}$ & GIS* & $\begin{array}{l}\text { Brain, } \\
\text { Liver }\end{array}$ \\
\hline Number of & & & & \\
\hline $\begin{array}{l}\text { Metastases } \\
\text { Previous unsuccessful } \\
\text { chemotherapy }\end{array}$ & - & $1-4$ & $5-8$ & $>8$ \\
\hline & - & - & Single drug & $>1$ drugs \\
\hline
\end{tabular}

*: Gastrointestinal system

\section{Evacuation of the Hydatidiform Mole}

Various methods have been proposed for the primary evacuation of HM. Among those, we can mention induction of labor, use of oxytoxic agents or prostaglandins, hysterectomy, dilatation, and curettage. However, currently, those nethods are rarely applied because of their high morbidity or limited efficacy. When aspiration curettage and medical therapy are compared, the requirement for chemotherapy is observed to be higher in medical therapy cases which is believed to be associated with incomplete evacuation of the mole ${ }^{(5)}$.
Recently, the preferred method for HM evacuation is aspiration curettage. Before evacuating the mole, the patient should be stabilized with regard to medical problems such as anemia, hypertension as a component of preeclampsia, and tachycardia as a finding of hyperthyroiditis. At least two units of blood should be kept ready. The mole should be evacuated under operating room conditions and general anesthesia. After the cervical dilatation, majority of the molar tissue can be evacuated by inserting a thick aspiration cannula into the uterine cavity and moving it inside in a rotational fashion. Following the evacuation of the mole by curettage, the uterine cavity should be checked for any remaining molar tissue with a sharp and large curette. Although the separate histopathologic evaluation of the material obtained by a sharp curette is a rare procedure, it may facilitate diagnosing invasive mole or choriocarcinoma cases. During the sharp curettage, traumatic touches should be avoided. If the uterus is not contracted or there is a myometrial invasion of the mole, performing a rigorous curettage may lead to uterine perforation. During the evacuation of molar pregnancy, intravenous oxytocin drips may be used. Thus, uterus contracts more effectively and blood loss is reduced. On the other hand, the use of oxytoxic agents during the evacuation of the mole causes overcontraction which may in turn lead to trophoblast embolization. If there is an extensive hemorrhage and uterus is not contracting, the use of oxytocin during the procedure and ergot preparations after the procedure, is inevitable. The uterine size shows direct correlation with therisk of perforation, hemorrhage, and pulmonary complication. In cases where the uterine size is below that of a 16-week pregnancy, these complications rarely occur. Some cases may present after the evacuation of molar tissues by miscarriage. In such cases, if the uterus is contracted, the cavity may be evacuated with a sharp curette. If the uterus is not large or contracted after the evacuation of the molar tissues, then the cavity can be evacuated with vacuum curettage and after achieving a uterine contraction, the cavity can be checked with a sharp curette ${ }^{(1,3-8)}$.

\section{The Management of Theca Lutein Cysts}

Today, two principle approaches should be borne in mind when faced with theca lutein cysts. First, one should have maximum patience, and second, one must approach them as conservative as possible. In presence 
of an apparent symptom, percutaneous and laparoscopic aspiration are rarely employed methods. The rate of cyst development in HM cases is reported to be $26.4 \%$, whereas complications such as rupture, hemorrhage, and infection are noted to occur in $3 \%$ of cases. The regression of the cysts continues up to 18 weeks following the achievement of hCG-negative status $(9)$. In HM, when laparoscopy or laparotomy is applied in cases presenting with acute abdominal symptoms associated with the rupture and torsion of theca lutein cysts, utmost attention should be paid to preserve the ovaries during surgery. In rupture cases, repairing the rupture site suffices. In torsion cases, ovarian function can be preserved by detorsion, even in delayed cases. The Importance of Laparoscopy, Laparotomy, and

\section{Hysterectomy in Hydatidiform Mole.}

Although rare, uterine perforation may occur during the evacuation of the mole. In such cases, vacuuming is discontinued and cannula is removed. Perforation site is determined by laparoscopy. Furthermore, under laparoscopic guidance, uterine cavity is emptied in a controlled fashion and uterine rupture is repaired. When the hemorrhage is excessive and the rupture is large or including vessels, the appropriate approach should be determined. Hysterectomy can be applied in patients who outlasted their reproductive age or in cases where the repair of the rupture is not possible, or when the hemorrhage threatens the life of the patient. Hysterectomy due to massive hemorrhage may be a lifesaving intervention(10).

In a study where GTD patients exhibiting serious hemorrhage and acute abdomen are considered for surgery; 17 patients had excessive vaginal hemorrhage and 7 had shock symptoms or hemiperitoneum findings. Eleven of them received total abdominal hysterecomy (TAH), or TAH + salpingoophorectomy, 2 cases received arterial ligation, 3 cases received embolization, and 1 case received vaginal suture due to metastatic nodule. Fifteen patients were subjected to chemotherapy and except one case, all the patients survived. In this study, authors noted that fertility-preserving surgeries are an alternative to hysterectomy in patients with a stable hemodynamic profile(11). In another study, hysterectomy was performed on 134 cases because of excessive vaginal hemorrhage and uterine perforation. In this study, 2 cases demonstrated hepatic metastases, whereas 3 cases exhibited lung metastases ${ }^{(12)}$.
If the family has no intention of having a child in the future, hysterectomy is recommended as an effective treatment. The risk of trophoblastic sequelae is reduced in hysterectomy. However, although hysterectomy eliminates the risk of local invasion, it is not efficient in preventing remote metastases. Furthermore, hysterectomy should be the method of choice in the presence of serious hemorrhage or sepsis. In addition, the presence of an uterine rupture that can not be repaired during the evacuation of the mole, warrants hysterectomy. The patients who received hysterectomy due to molar pregnancy should be monitored closely, as well(13). During the hysterectomy, oophorectomy should not be performed even in the presence of theca lutein cysts in the ovaries ${ }^{(14)}$.

In one study, 7 of 100 cases diagnosed with HM were treated by hysterectomy ${ }^{(15)}$. Hysterectomy can be performed in HM cases with coexisting conditions such as uterine myoma or cervical cancer $(1-3,7)$.

Bahar AM et al. conducted a study on patients above 35 years of age and $10.0 \%$ of the cases that received hysterectomy required chemotherapy, whereas among patients who did not undergo hysterectomy, same rate was 33.4, however, the difference between was not statistically significant ${ }^{(16)}$. In another study, among 5976 cases who presented with molar pregnancy diagnosis, 301 required chemotherapy, while 40 patients received hysterectomy. Among the 40 cases that underwent hysterectomy, the most common indications for hysterectomy were chemotherapy-resistant disease $(30 \%)$, primary treatment $(27.5 \%)$, vaginal hemorrhage (17.5\%), and intraabdominal bleeding (17.5\%). In this case series, ten of the patients with molar pregnancy diagnosis passed away, and 4 of them were in the hysterectomy group ${ }^{(17)}$.

\section{Surgical Management of Malignant GTDs Pretreatment Dilatation and Curettage}

In a considerable amount of cases receiving treatment due to malignancy after HM treatment, the tumor is located in the uterus. Such cases present with large and soft uterus. Furthermore, vaginal hemorrhage is frequently determined. In $20 \%$ of patients with a history of dilatation and curettage after HM, spontaneous remission is observed. The predicted benefits of pretreatment dilatation and curettage are reduction of the tumor size and ability to diagnose choriocarcinoma histologically. However, there are two important risks 
associated with this procedure: perforation and infection. In $8.1 \%$ of cases receiving pretreatment dilatation and curettage, uterine perforation develops, whereas $66 \%$ of patients with uterine perforation require hysterectomy (18).

In one study, among low-risk, persistent cases with a history of secondary curettage as a part of their treatment, 9.4\% required chemotherapy, whereas all the cases that did not receive secondary curettage required chemotherapy $(\mathrm{p}<0.001)$. On the other hand, $4.8 \%$ of the cases that received curettage developed major complications in the form of uterine perforation and hemorrhage, for which conservative treatment was applied on all of them. Curettage was noted to possibly have a debulking effect(19).

In patients who received dilatation and curettage, trophoblastic tissue is not frequently observed. The reason behind this might be myometrial lozalization of the tumor or presence of tumor in extra-uterine sites (20). Thus, although the use of dilatation and curettage in cases without excessive hemorrhage is limited, there are some authors advocating that it should not be recommended because of the fact that it is capable of increasing the morbidity.

\section{GTN Confined to the Uterus}

In cases with GTN confined to the uterus, the disease can generally be managed by chemotherapy. Chemotherapy is regarded as the first choice of treatment since most of the patients are young and still fertile. With or without hysterectomy, 100\% remission is achieved by chemotherapy in nonmetastatic or lowrisk metastatic disease. However, in cases that received primary hysterectomy, the length of hospital stay is shorter and the dose of chemotherapy is lower.

In patients that do not respond to the initial chemotherapy, remission can be achieved by performing delayed hysterectomy without needing chemotherapy with multiple drugs. Hysterectomy can be performed under the influence of chemotherapy. Applying hysterectomy does not cause an increase in the morbidity and the tumoral expansion can be checked during the surgery $(21,22)$. In non-metastatic and lowrisk metastatic GTD, adjuvant hysterectomy reduces the overall dose of chemotherapy and is reported as an option in cases with lesions confined to the uterus, if the patient does not have the intention of childbearing (23). Generally, hysterectomy is performed as TAH which enables the exploration of the entire abdomen. Furthermore, in cases undergoing hysterectomy, adnexa can be preserved. Furthermore, vaginal hysterectomy can be performed without inducing significant complications $^{(8)}$. In one study consisted of 25 patients diagnosed with GTN, 9 received TAH +lymph node biopsy, 11 cases received TAH + bilateral salpingooophorectomy, and 3 cases received hysterectomy and unilateral parametrectomy. The survival rate in this study was reported as $88 \%(24)$.

According to the database of Sheffield Trophoblastic Tumor Center, among 8.860 cases diagnosed as GTD, $7.1 \%$ required chemotherapy and $0.71 \%$ (62 cases) underwent hysterectomy. Most common hysterectomy indications were resistance against chemotherapy in $35.5 \%$ and major hemorrhage in 33.9\%. Emergency hysterectomy was applied in $35 \%$ of the cases. Mean FIGO risk score was 6.5 in the hysterectomy group. The detected pathologies were chorio cancer in 23 cases, invasive mole in 10 cases, and PSTT in 9 cases. Half of the cases required chemotherapy, while 93.5\% showed remission and 7 developed relapse; 3 of the patients in this group were cured, whereas 2 passed away due to the disease ${ }^{(25)}$. One other study investigated the indications of 18 cases that were subjected to abdominal hysterectomy because of GTN diagnosis. Five cases had suspected lesions confined to the uterus, 7 cases had chemotherapy-resistant uterine lesion, 4 cases had hemoperitoneum, and 2 cases had other gynecologic pathologies. The histopathologic results of the hysterectomy materials revealed chorio cancer in 9 cases, invasive mole in 6 cases, and PSTT in 1 case, while one of the cases could not be diagnosed definitively(26).

In patients with high-risk metastatic disease, if the extra-uterine expansion is controlled or has a limited character, primary or delayed surgical treatment can be curative. Hysterectomy is not recommended for diffuse extrauterine disease. Hysterectomy will not show a curative effect on such patients and it will even increase the morbidity ${ }^{(27)}$.

In a study conducted by Lurain JR et al., 28 surgical procedures were performed on 24 high-risk GTN cases: 17 hysterectomy, 5 lung resection, 1 salpingectomy, 1 uterine wedge resection, 1 small intestine resection, 2 suturing of the liver or uterus, and 1 uterine artery embolization. $87.5 \%$ of those cases survived and $88 \%$ of the hysterectomy cases were cured. Of 5 patients 
with pulmonary metastatic foci, 4 were cured with pulmonary resection. Furthermore, cases that underwent suturing of the uterus, small intestine resection, salpingectomy, and uterine wedge resection, did not pass away(28).

\section{Management of GTN with Pulmonary Metastasis}

The most common remote metastase site of GTNs is lungs. Therefore, the most common surgical treatment methods are thoracotomy and pulmonary resection or lobectomy ${ }^{(21)}$. Prior to the thoracotomy, presence of metastases in other sites should be eliminated. In this aim, abdominopelvic tomography can be used. In order to verify the absence of active pelvic metastase, other modalities such as pelvic US, angiography, and MRI can be used, as well.

According to an old study, the selection criteria for patients that are eligible for thoracotomy are: (1) being eligible for surgery, (2) having primary malignancy under control, (3) absence of another metastase site, (4) having a pulmonary lesion showing a solitary character, (5) showing a hCG level below mIU/ml. In the same study, among patients meeting these criteria, survival rate after pulmonary resection was 93\%, whereas it was $0 \%$ in patients not meeting the criteria (29). In another study, thoracotomy was performed for therapeutic purposes in 11 cases and for verification of the diagnosis in 8 cases. According to this study, thoracotomy has been used for therapeutic purposes since 1980 . Ten $(90.9 \%)$ out of 11 cases that were resistant against chemotherapy, demonstrated remission. The optimal criteria for achievement of a remission by thoracotomy were Stage III disease, a preoperative $\mathrm{hCG}$ value $<1.500 \mathrm{mIU} / \mathrm{ml}$, and presence of chemotherapy-resistant solitary nodules ${ }^{(30)}$.

In one study where 62 pulmonary metastasis cases were subjected to lobectomy or more limited lung surgery, the patients were categorized into 3 groups: Recurrent (Group A), drug-resistant (Group B), and those that respond to chemotherapy but demonstrate residual pulmonary lesion (Group C). In Group C, 12\% of the cases were tumor-positive. The remisison rate was $100 \%$ and there was no relapse in this group. Complete remission rates in Group $\mathrm{A}$ and $\mathrm{B}$ were $88.9 \%$ and $78.6 \%$, respectively, whereas the relapse rates were $14.3 \%$ and $15.0 \%$, respectively. The patients who responded well to the chemotherapy and those with a pulmonary residual lesion, did not require surgery, however, the cases that did not respond well despite receiving more than 4 chemotherapy regimes or more than 13 cures, were evaluted to require surgery (31). In cases where the disease is evaluated to be cured based on negative hCG values following chemotherapy, there is no need for removal of persistent nodules of the lungs. The resorption of these nodules sometimes lasts for months following chemotherapy in certain patients $(32)$.

\section{Management of GTN with CNS Metastasis}

Involvement of CNS in GTN disease indicates poor prognosis. Highly vascular nature of metastatic foci constitutes a risk of hemorrhage. In patients with CNS involvement, a certain number of patients pass away due to hemorrhage or brain edema during the early treatment period. Therefore, craniotomy combined with systemic and intrathecal chemoratherapy, is applied early in the treatment ${ }^{(33)}$. Yang JJ et al. performed a combination of craniotomy and chemotherapy on 13 of 63 cases with brain metastasis due to elevated intracranial pressure and intracranial hemorrhage; 7 of them showed total remission, 5 showed partial remission, and 1 patient passed away. They underscored the importance of emergency craniotomy in their study (34). Another therapeutic approach towards cases with CNS metastasis is to apply a combined therapy of chemotherapy and external radiotherapy ${ }^{(21)}$. In one study, 42 patients with brain metastasis were treated with combined chemotherapy and external radiotherapy, while 7 cases received craniotomy ${ }^{(35)}$. In a more recent study, among 4 cases with Stage IV GTN and brain metastasis, all cases had pulmonary metastasis and 1 case had multiple liver metastases. Only one of those cases was asymsptomatic. The entire patient group received chemotherapy. Craniotomy was performed on 3 patients for removal of the lesions before or during the initial chemotherapy session, whereas the remaining patient underwent stereotactic radiosurgery for removal of 2 lesions following chemotherapy. Thus, none of the patients received whole brain irradiation or intrathecal methotrexate. All the patients were reported to be in remission within the long-term follow-up (1224 months) ${ }^{(36)}$.

\section{Management of PSTT}

Most of the cases present with a tumor localized in the uterus and those with extensive lesions are treated with 
combination of surgery and chemotherapy. The primary treatment of the disease is hysterectomy. In cases with local tumors involving individuals that want to retain fertility, dilatation and curettage may be performed. Since metastasis in the ovaries is a rare event, oophorectomy may not be applied(37). In one study, among 34 cases diagnosed with PSTT, 47\% were found to have a disease confined to uterus, whereas all 7 who passed away were found to have lung metastasis. When the patients who died were excluded, the primary therapy was hysterectomy in 9 cases and dilatation/ curettage in 2 cases $^{(38)}$. In another study consisted of 17 patients diagnosed with PTSS, among Stage I cases, 6 patients who underwent hysterectomy alone, 1 patient that received only chemotherapy, and 1 patient who underwent a combination of hysterectomy and chemotherapy, survived. On the other hand, among 9 patients with either Stage III or IV disease, only 4 survived after hysterectomy and chemotherapy treatment ${ }^{(39)}$.

\section{Other Surgical Procedures}

Although rare, ectopic pregnancies may be molar pregnancies and there are case reports on this topic in the literature ${ }^{(40)}$. Two of those case reports involve patients who were diagnosed as ruptured tubal ectopic pregnancy, but were found to have complete HM during surgery ${ }^{(41)}$. Choriocarcinoma may develop during pregnancy, as well. In the literature, there is only one case that has been treated with salpingectomy followed by chemotherapy ${ }^{(42)}$. Tubal carcinoma may be removed by laparoscopic surgery, as well(43).

Vaginal metastases may lead to excessive hemorrhage during biopsy. However, in cases that do not respond to chemotherapy, biopsy and resection should be considered. Chemotherapy should be the first choice for patients with intra-abdominal metastasis, however, hemorrhage in tumoral foci may require resection of the involved structures $(21)$.

In renal metastases, patients with a tumor confined to kidneys and those with a unilateral involvement, are observed to survive (44).

\section{Fertility-preserving Surgeries}

According to a study performed in 1965, fertilitypreserving surgery can be performed in GTN cases. However, uterine perforation may develop in invasive HM. In such cases, instead of applying hysterectomy, performing myometrial repair after segmental uterine resection, may help preservation of uterus ${ }^{(45)}$. In one study, a patient with persistent and chemotherapyresistant uterine GTN was treated by segmental uterine resection followed by uterine reconstruction, and yet she gave birth to 2 babies after this treatment ${ }^{(46)}$. In one 18-year-old case with no child, phantom hCG was ruled out due to low hCG levels and increased uptake was detected on PET images. The lesion was removed while the uterus was preserved, and clinical remission was achieved after 2 cures of multiagent chemotherapy (47). In two cases where chemotherapy was applied because of persistent trophoblastic disease, choriocancer-related perforation was found during the emergency laparotomy and those areas were resected. Both patients developed a term pregnancy thereafter (48).

Choriocarcinoma development from cornual pregnancy is a very rare event. In one case, wedge resection was performed upon detection of a mass over the cornual area during a laparoscopy and pathological analysis verified the choriocarcinoma diagnosis $(49)$.

In another study, in one of 5 cases with PSTT diagnosis, fertility-preserving surgery was achieved via removal of the tumor by operative hysterescopic resection combined with chemotherapy ${ }^{(50)}$. Fertility-preserving surgery can be applied by partial hysterectomy in PSTT cases $^{(51)}$.

\section{Conclusion}

HM requires a close follow-up after evacuation. Early diagnosis of a malignant potential should provide effective therapy. One should consider that GTNs develop after other non-HM pregnancies and appropriate treatment should be delivered by determining the extension of the disease via clinical and diagnostic methods. It should be borne in mind that the primary treatment for GTN is effective chemotherapy. In GTDs, surgical treatment is applied for two purposes: (1) Prevention of acute mortalities associated with hemorrhage. Intracerebral and intraabdominal interventions require emergency surgery. Furthermore, in cases with CNS involvement, decompression against hemorrhage and edema is a life saving intervention. (2) The involved structures that do not respond to the therapy should be removed. It is important to ascertain that there is no tumor extension beyond the area that is planned to be resected. 
Furthermore, one should always remember that all the approaches associated with GTDs are of multidisciplinary character.

\section{REFERENCES}

1. Özalp S.: Gestasyonel trofoblastik tümörler, Klinikte Obstetrik ve Jinekoloji, Editörler, Çiçek N., Mungan T, Güneş Tıp Kitabevleri Ltd. Şti, Ankara, 2006, sf.797- 807.

2. Özalp S.: Gestasyonel trofoblastik hastalıklar, Ed. Ayhan A., Durukan T., Günalp S., Gürgan T., Önderoğlu LS., Yaralı H., Yüce K.: Temel Kadın Hastalıkları ve Doğum Bilgisi, İkinci Bask1, Güneş Tıp Kitabevleri, Ankara, 2008, sf. 132131 .

3. Ozalp S.S., Tanir M.H.: Gestational Trophoblastic Diseases, Text Book of Gynaecological Oncology, ed. Ayhan A., Gultekin M., Dursun P.,Turkish Society of Gynaecological Oncology (TSGO), European Society of Gynaecological Oncology (ESGO) and European Network of Young GYN Oncologists (ENYGO), Güneş Publishing, Ankara, 2009, Turkey, Bölüm 46, sf.225- 32.

4. Pecorelli S, Ngan HYS, Hacker NF (eds.). Trophoblastic diseases. Staging Classifications and Clinical Practice Guidelines for Gynecological Cancers, A collaboration between FIGO and IGCS, third ed., 2006, sf. 122- 45.

5. Tidy JA, Gillespie AM, Bright N, Radstone CR, Coleman RE, Hancock BW. Gestational trophoblastic disease: a study of mode of evacuation and subsequent need for treatment with chemotherapy. Gynecol Oncol 2000; 78: 309- 12.

6. Altıntaş A. Mol hidatidiformda tanı, yaklaşım ve profilaktik kemoterapi. Özalp S, ed. Gestasyonel Trofoblastik Hastalıklar. Eskişehir: Anadolu Üniversitesi Basımevi, 1997; 119- 35.

7. Özalp S, Hassa, H, Şener T, Minsin T. Elli dokuz mol hidatidiform olgusunun değerlendirilmesi. Jinekoloji ve Obstetrik Bülteni 1998; 7: 51- 6.

8. Lurain JR.Gestational trophoblastic disease II: classification and management of gestational trophoblastic neoplasia. Am J Obstet Gynecol. 2011; 204: 11- 8 .

9. Montz FJ, Schlaerth JB, Morrow The natural history of theca lutein cysts.Obstet Gynecol. Obstet Gynecol 1988; 72: 247 51

10. Topuz S, Iyibozkurt C, Mete O, Akhan S, Salihoğlu Y, Bengisu E, Berkman S.Life-saving hysterectomy in choriocarcinoma: presentation of two cases. Eur J Gynaecol Oncol. 2008; 29: 664- 5 .

11. Tse KY, Chan KK, Tam KF, Ngan HY. 20-year experience of managing profuse bleeding in gestational trophoblastic disease. J Reprod Med. 2007; 52: 397- 401.

12. Cagayan MS, Magallanes MS.The role of adjuvant surgery in the management of gestational trophoblastic neoplasia. $\mathrm{J}$ Reprod Med. 2008; 53: 513- 8

13. Curry SL, Hammond CB, Tyrey L, Creasman WT, Parker RT Hydatidiform mole: diagnosis, management, and longterm followup of 347 patients. Obstet Gynecol.1975; 45: 18.

14. Berkowitz RS, Goldstein DP. Gestational trophoblastic Neoplasia. Practical Gynecologic Oncology. Berek JS, Hacker NF, ed, Lippincott Williams and Wilkins, USA, 2000, s. 61538.

15. Ayhan A, Özalp S. Benign trofoblastik Hastalıklar (Hydatidiform mole) 100 olgunun klinik incelenmesi. Hacettepe Tip / Cerrahi Bülteni 1982; 15: 56- 62.

16. Bahar AM, el-Ashnehi MS, Senthilselvan A. Hydatidiform mole in the elderly: hysterectomy or evacuation? Int J Gynaecol Obstet 1989; 29: 233- 8

17. Pisal NV, North C, Tidy JA, Hancock BW. Role of hysterectomy in management of gestational trophoblastic disease. XIth World Congress on Gestational Trophoblastic Disease, Bildiri Kitabı. 27-31 Ekim 2001, Santa Fe, A.B.D

18. Schlaerth JB, Morrow CP, Rodriguez M. Diagnostic and therapeutic curettage in gestational trophoblastic disease.Am J Obstet Gynecol 1990; 162: 1465- 70.

19. van Trommel NE, Massuger LF, Verheijen RH, Sweep FC, Thomas CM. The curative effect of a second curettage in persistent trophoblastic disease: a retrospective cohort survey. Gynecol Oncol. 2005; 99: 6- 13 .

20. Berkowitz RS, Desai U, Goldstein DP, Driscoll SG, Marean AR, Bernstein MR. Pretreatment curettage-A predictor of chemotherapy response in gestational trophoblastic neoplasia. Gynecol Oncol. 1980; 10: 39- 43.

21. Feng F, Xiang Y. Surgical management of chemotherapyresistant gestational trophoblastic neoplasia. Expert Rev Anticancer Ther. 2010; 10: 71- 80.

22. Feng F, Xiang Y.Surgical management of chemotherapyresistant gestational trophoblastic neoplasia.Expert Rev Anticancer Ther. 2010; 10: 71- 80.

23. Clark RM, Nevadunsky NS, Ghosh S, Goldstein DP, Berkowitz RS. The evolving role of hysterectomy in gestational trophoblastic neoplasia at the New England Trophoblastic Disease Center. J Reprod Med. 2010: 194- 8.

24. Doumplis D, Al-Khatib K, Sieunarine K, Lindsay I, Seckl M, Bridges J, Smith JR. A review of the management by hysterectomy of 25 cases of gestational trophoblastic tumours from March 1993 to January 2006. BJOG. 2007; 114: 116871. 
25. Alazzam M, Hancock BW, Tidy J. Role of hysterectomy in managing persistent gestational trophoblastic disease. J Reprod Med. 2008; 53: 519- 24.

26. Pongsaranantakul S, Kietpeerakool C.: Hysterectomy in gestational trophoblastic neoplasia: Chiang Mai University Hospital's experience. Asian Pac J Cancer Prev. 2009; 10 311- 4 .

27. Hanna RK, Soper JT . The role of surgery and radiation therapy in the management of gestational trophoblastic disease. Oncologist. 2010; 15: 593- 600.

28. Lurain JR, Singh DK, Schink JC.Role of surgery in the management of high-risk gestational trophoblastic neoplasia J Reprod Med. 2006; 51: 773- 6.

29. Tomoda Y, Arii Y, Kaseki S, Asai Y, Gotoh S, Suzuki T, Kondoh T, Imaizumi M. Surgical indications for resection in pulmonary metastasis of choriocarcinoma. Cancer. 1980; 46: 2723- 30 .

30. Fleming EL, Garrett L, Growdon WB, Callahan M, Nevadunsky N, Ghosh S, Goldstein DP, Berkowitz RS. The changing role of thoracotomy in gestational trophoblastic neoplasia at the New England Trophoblastic Disease Center. J Reprod Med. 2008; 53: 493-8.

31. Cao Y, Xiang Y, Feng F, Wan X, Yang X.Surgical resection in the management of pulmonary metastatic disease of gestational trophoblastic neoplasia.Int J Gynecol Cancer. 2009; 19: 798-801.

32. Wong LC, Ma HK. Persistent chest opacity in trophoblastic disease: is thoracotomy justified? Aust N Z J Obstet Gynaecol. 1983; $23: 237-40$.

33. Rustin GJ, Newlands ES, Begent RH, Dent J, Bagshawe KD. Weekly alternating etoposide, methotrexate, and actinomycin/ vincristine and cyclophosphamide chemotherapy for the treatment of CNS metastases of choriocarcinoma. J Clin Oncol. 1989; 7: 900- 3

34. Yang JJ, Xiang Y, Yang XY, Wan XR.Emergency craniotomy in patients with intracranial metastatic gestational trophoblastic tumor. Int J Gynaecol Obstet. 2005; 89: 35- 8.

35. Evans AC Jr, Soper JT, Clarke-Pearson DL, Berchuck A, Rodriguez GC, Hammond CB. Gestational trophoblastic disease metastatic to the central nervous system. Gynecol Oncol 1995; 59: 226- 30 .

36. Soper JT, Spillman M, Sampson JH, Kirkpatrick JP, Wolf JK, Clarke-Pearson DL.High-risk gestational trophoblastic neoplasia with brain metastases: individualized multidisciplinary therapy in the management of four patients. Gynecol Oncol 2007; 104: 691- 4

37. Berkowitz BJ, Jones JG, Merkatz IR, Runowicz CD. Ovarian conservation in placental site trophoblastic tumor. Gynecol
Oncol. 1990; 37: 239- 43.

38. Papadopoulos AJ, Foskett M, Newlands ES, Seckl MJ. Placental site trophoblastic tumour (PSTT): 25 years experience at the Charing Cross Hospiatal, London. XIth World Congress on Gestational Trophoblastic Disease, Bildiri Kitabı. 27-31 Ekim 2001, Santa Fe, A.B.D.

39. Hassadia A, Gillespie A, Tidy J, Everard R G N J, Wells M, Coleman R, Hancock B. Placental site trophoblastic tumour: clinical features and management. Gynecol Oncol. 2005; 99: $603-7$.

40. Hwang JH, Lee JK, Lee NW, Lee KW. Molar ectopic pregnancy in the uterine cornus. J Minim Invasive Gynecol. 2010; 17: 239- 41 .

41. Abdul MA, Randawa AJ, Shehu SM. Ectopic (tubal) molar gestation: report of two cases. Niger J Clin Pract. 2008; 11: 3923.

42. Gálvez CR, Fernández VC, de Los Reyes JM, Jaén MM, Teruel RG. Primary tubal choriocarcinoma. Int J Gynecol Cancer. 2004; 14: 1040- 4.

43. Nayama M, Lucot JP, Boukerrou M, Collinet P, Cosson M, Vinatier D. Tubal choriocarcinoma: a case report and review of the literature. J Gynecol Obstet Biol Reprod. 2007; 36: 836.

44. Soper JT, Mutch DG, Chin N, Clarke-Pearson DL, Hammond CB. Renal metastases of gestational trophoblastic disease: a report of eight cases. Obstet Gynecol 1988; 72: 796- 8.

45. Wilson RB, Beecham CT, Symmonds RE, Conservative surgical management of chorioadenoma destruens. Obstet Gynecol. 1965; 26: 814- 20 .

46. Case AM, Wilson S, Colgan TJ, Greenblatt EM. Fertilitysparing surgery, with subsequent pregnancy, in persistent gestational trophoblastic neoplasia: case report. Hum Reprod; 2001; 16: 360- 4 .

47. Rojas-Espaillat L, Houck KL, Hernandez E, Berkowitz RS. Fertility-sparing surgery for persistent gestational trophoblastic neoplasia in the myometrium: a case report. J Reprod Med. 2007; 52: 431- 4 .

48. Behtash N, Ansari S, Sarvi F. Successful pregnancy after localized resection of perforated uterus in choriocarcinoma and a literature review. Int J Gynecol Cancer. 2006; 16: 1: 445- 8 .

49. Rotas M, Khulpateea N, Binder D.Gestational choriocarcinoma arising from a cornual ectopic pregnancy: a case report and review of the literature. Arch Gynecol Obstet. 2007; 276: 645- 7.

50. Machtinger R, Gotlieb WH, Korach J, Fridman E, Apter S, Goldenberg M, Ben-Baruch G. Placental site trophoblastic tumor: outcome of five cases including fertility preserving 
management. Gynecol Oncol. 2005; 96: 56- 61.

51. Pfeffer PE, Sebire N, Lindsay I, McIndoe A, Lim A, Seckl
MJ Fertility-sparing partial hysterectomy for placental-site trophoblastic tumour. Lancet Oncol. 2007; 8: 744- 6 